\title{
Emergency Medications Order for Neonates and Pediatrics: A Standardized Concentration System in Saudi Arabia
}

\author{
Yousef Ahmed Alomi* ${ }^{(D}$, The \\ Former General Manager of General \\ Administration of Pharmaceutical Care, The \\ Former Head, National Clinical pharmacy and \\ pharmacy practice, The Former Head, Phar- \\ macy R\&D Administration, Ministry of Health, \\ Riyadh, SAUDI ARABIA.
}

Fatimah Al-Doughan, College of Pharmacy, Pharmacy Practice Department, King Faisal University, Alahssa, Alhassa, SAUDI ARABIA.

Yasir Ahmed Ibrahim, Head of

Pharmacy Practice Department, Pharmacy Practice Department, College of Clinical

Pharmacy, King Faisal University, Alahssa, SAUDI ARABIA.

Hussam Saad Almalki, Supervisor of IV admixture services, Aleman Hospital, Ministry of Health, Riyadh, SAUDI ARABIA.

Nouf Alaza, Director of medication safety officer, pharmacy services, Alyammama hospital, Ministry of Health, Riyadh, SAUDI ARABIA

Malika Alshamari, Head, Pharmacy services, Alyamma Hospital, Ministry of Health, Riyadh, SAUDI ARABIA.

\section{Correspondence:}

Dr. Yousef Ahmed Alomi, The Former General Manager of General Administration of Pharmaceutical Care, The Former Head, National Clinical pharmacy and pharmacy practice, The Former Head, Pharmacy R\&D Administration, Ministry of Health, Riyadh, SAUDI ARABIA

Phone no: +966 504417712

E-mail:yalomi@gmail.com

\section{Received: 20-03-2019;}

Accepted: 12-07-2019

Copyright: $\odot$ the author(s), publisher and licensee International Journal of Pharmacology and Clinical Sciences. This is an open-access article distributed under the terms of the Creative Commons Attribution Non-Commercial License, which permits unrestricted non-commercial use, distribution, and reproduction in any medium, provided the original work is properly cited.

This is an open access article distributed under the terms of the Creative Commons Attribution-NonCommercial-ShareAlike 4.0 License

Access this article online

\begin{tabular}{|c|c|}
\hline & www.ijpcs.net \\
\hline & \\
\hline
\end{tabular}

\section{ABSTRACT}

The national pediatric pharmacy program was founded in 2014. It is a part of the pharmacy strategic plan. This program has implemented several projects including preparation and administration of intravenous medication to neonates and pediatric patients. The complementary new initiatives program is the neonates and pediatrics standardized concentration of emergency medications with an emphasis on medications used to treat critically ill patients and in emergency department. This new project has physician order form with selected dilutions, concentrations and route of administration. The form may be converted to a computerized order form. The new initiatives of the project may be implemented through project management tools. The project prevents drug-related problem and decrease economic burden on healthcare system for neonates and pediatrics hospitals in the Kingdom of Saudi Arabia.

Keywords: Emergency, Medications, Neonates, Pediatrics, Standardized, Concentration, Saudi Arabia.

\section{INTRODUCTION}

The general administration of pharmaceutical care established the national medication safety program at the Ministry of Health (MOH) hospitals in 2013. ${ }^{[1]}$ The program consisted of several strategic elements including the standardized concentration of emergency medications with an emphasis on neonates and pediatrics. The Institute of Safe Medication Practice in the United States of America (USA) considers the emergency medications as high alert medications and several precautions should be taken to prevent medication errors especially with neonates and pediatric populations. ${ }^{[2-5]}$ The local accreditation body of Saudi Central Board for Accreditation of Healthcare Institutions (CBAHI) published essential safety requirements for high alert medications. ${ }^{[6]}$ The standardized concentration of medications is a crucial element of Institute of Safe Medication Practice (ISMP) self-assessment of hospitals' medication safety. Various studies conducted in Saudi Arabia of a national assessment of medications safety during Hajj period. ${ }^{[7-12]}$ Previous reports have shown least score of medication safety assesmnet studies were for the demand of the standardized contraction for medication and administration. ${ }^{[9,10]}$ The new initiative program of medications safety and total management in the pharmacy practice was conducted at three major hospitals in Riyadh city, Saudi Arabia. This was conducted to prevent drug-related problems and improve clinical outcome of patient during drug therapy ${ }^{[13-14]}$ The author is not familiar with any initiative projects in Saudi Arabia, Gulf, or in the Middle Eastern countries describing the standardized concentration of emergency medications for neonates and pediatrics.

\section{Neonates and Pediatrics Emergency Medications Standardized Concentration in Saudi Arabia}

The standardized formulation of emergency medications included cardiopulmonary resuscitation requirements for neonates and pediatrics. The formulation was derived from the current literature and guidelines for neonates and pediatric population with an average of $70 \mathrm{~kg}$ body weight. The medication consisted of dopamine, dobutamine, epinephrine, norepinephrine and so on. The physician order form consisted of several parts including demographic data of the patients, medications names, the standardized and maximum concentration, the type of crystallized fluid, the route of administration through a central or peripheral vein, the dosing range requirements as explored in physician order entry form (Figure $1)$.

\section{SWOT Analysis}

In this study, we performed strengths, weaknesses, opportunities and threats (SWOT) analysis to analyze the benefits and risks to the project. The strength of the neonates and pediatrics physician order forms including all information of common medications used in emergency situations, dosing of medications, fixed standardized concentration of emergency medications, the method of medications administration and prevention of mistakes in writing emergency medications orders are available for neonates and pediatrics. The weaknesses are including dosing drips used outside another's resources and it cannot apply to renal or hepatic failure. The opportunity that is including it is a straightforward form to convert them into computerized and physician order entry and it can calculate 
statistical information of all emergency medications. The threat points include the physician or pharmacist have not used the standardized concentration.

\section{Implementations Steps of Emergency Medications for Neonates and Pediatrics}

The pharmacy department organizes consultation with the expert pharmacist especially for the intravenous admixture and expert clinical pharmacists in critical care involving in the committee. The committee should extensively review the draft and then approve the standardized concentration form of neonates and pediatrics emergency medications form. The head of the committee will contact the surgical and medical department of neonates and pediatric patients for final revisions of the draft and its approval. The head of pharmacy services will submit the final draft of the formulation to Pharmacy and Therapeutic Committee for review and approval. The head of the committee will collaborate with the computer department in order to prepare the electronic order forms. The pharmacy education coordinator coordinates with all the departments including nursing, surgical and medical department in order to educate and train the medical and pharmacy staff about the formulation. The quality management department will set up the Key Performance Indicators (KPIs) in order to measure the impact of the project. All teams related to the department of pharmacy including emergency medications preparation and clinical pharmacist will obtain the KPI of the project retrospectively in the past 3-6 months. Then, the collected data were prospectively analyzed in the following months. The head of the committee will contact the nursing and medical development to start project stepwise of one medical department as the pilot trial. The pharmacist will review the pilot trial and correct the form according to the feedback shared by the pharmacy consultation committee. The team will share the document with all the personnel of the medical department and surgical department who will review and change the medication accordingly. The head of the committee will share it with all the staff members of the hospital including adult's critical care, who will review it and adjust the formulation accordingly. The coordinator of the quality management will measure the impact of the project by comparing the KPIs before and after starting the project. The head of the committee will analyze the results and review them. The head of the pharmacy will submit the final report to Pharmacy and Therapeutic committee for final touch and comments. The consultation team will review the final comments and update it accordingly. The project will continue until next year

\section{CONCLUSION}

The neonates and pediatrics standardized concentration of emergency medications is a new program which is applied first time at the MOH hospitals in Saudi Arabia, Gulf and Middle Eastern countries. It prevents emergencyrelated adverse events and improve neonates and pediatrics clinical outcomes.

\section{ACKNOWLEDGEMENT}

None.

\section{CONFLICT OF INTEREST}

The authors declare that there are no conflicts of interest.

\section{ABBREVIATIONS}

KSA: Kingdom of Saudi Arabia; MOH: Ministry of Health; USA: United States of America; CBAHI: Saudi Central Board for Accreditation of Healthcare Institutions; ISMP: Institute of Safe Medication Practice; SWOT: Strengths, Weaknesses, Opportunities and Threats; KPIs: Key Performance Indicators.

\section{ORCID ID}

Yousef Ahmed Alomi org/0000-0003-1381-628X

https://orcid.

\section{REFERENCES}

1. Alomi YA. National Medication Safety Program at Ministry of Health in Saudi Arabia. J Pharmacovigi. 2015;3(5):1-2.
2. Irwin D, Vaillancourt $R$, Dalgleish $D$, Thomas $M$, Grenier S, Wong E, et al. Standard concentrations of high-alert drug infusions across paediatric acute care. Paediatr Child Health. 2008;13(5):371-6.

3. Lucas AT, Rowe E, Eckel SF. Determining the Need for Standardized Infusions and Concentrations at Hospitals within North Carolina. Hosp Pharm. 2016;51(3):237-45.

4. Larsen GY. Standard Drug Concentrations and Smart-Pump Technology Reduce ContinuousMedication-Infusion Errors in Pediatric Patients. Pediatrics. 2005;116(1):e21-5.

5. Phillips MS. Standardizing i.v. infusion concentrations: National survey results. Am J Heal Pharm. 2011;68(22):2176-82.

6. Medication Management (MM). In: National Hospital Standards. $2^{\text {nd }}$ Editio. Saudi Central Board for Accreditation of Healthcare Institutions. 2015;194211. Available from: http://www.cbahi.gov.sa

7. Alomi YA, Khayat NAY, Baljoon MJ, Bamagaus YA, Jumah HMA. National Survey of Hospital Medication Safety Practice during Mass Gathering (Haji-2016) in Makkah, Saudi Arabia: Patient Information. J Pharm Pract Community Med. 2017;3(4s):s29-35.

8. Alomi YA, Khayat NAY, Baljoon MJ, Bamagaus YA, Jumah HMA. National Survey of Hospital Medication Safety Practice during Mass Gathering (Haij2016) in Makkah, Saudi Arabia: Drug Information. J Pharm Pract Community Med. 2017;3(4s):s8-14.

9. Alomi YA, Khayat NAY, Baljoon MJ, Bamagaus YA, Jumah HMA. National Survey of Hospital Medication Safety Practice during Mass Gathering (Hajj2016) in Makkah, Saudi Arabia: Medication Preparation and Dispensing. J Pharm Pract Community Med. 2017; 3(4s):S36-S42.

10. Alomi YA, Khayat NAY, Baljoon MJ, Bamagaus YA, Jumah HMA. National Survey of Hospital Medication Safety Practice during Mass Gathering (Hajj-2016) in Makka, Saudi Arabia: Medication Administration. J Pharm Pract Community Med. 2017;3(4s):s22-8.

11. Alomi YA, Khayat NAY, Baljoon MJ, Bamagaus YA, Jumah HMA. National Survey of Hospital Medication Safety Practice during Mass Gathering (Hajj-2016) in Makkah, Saudi Arabia: Environmental Culture and Staff Competency. J Pharm Pract Community Med. 2017;3(4s):s15-21.

12. Alomi YA, Khayat NAY, Baljoon MJ, Bamagaus YA, Jumah HMA. National Survey of Hospital Medication Safety Practice during Mass Gathering (Hajj2016) in Makkah, Saudi Arabia: Patient Education, Quality Process and Risk Management. J Pharm Pract Community Med. 2017;3(4s):s1-7.

13. Murray KL, Wright D, Laxton B, Miller KM, Meyers J, Englebright J. Implementation of standardized pediatric i.v. medication concentrations. Am J Heal Pharm. 2014;71(17):1500-8.

14. Sowan AK, Vaidya VU, Soeken KL, Hilmas E. Computerized orders with standardized concentrations decrease dispensing errors of continuous infusion medications for pediatrics. J Pediatr Pharmacol Ther. 2010;15(3):189-202. 


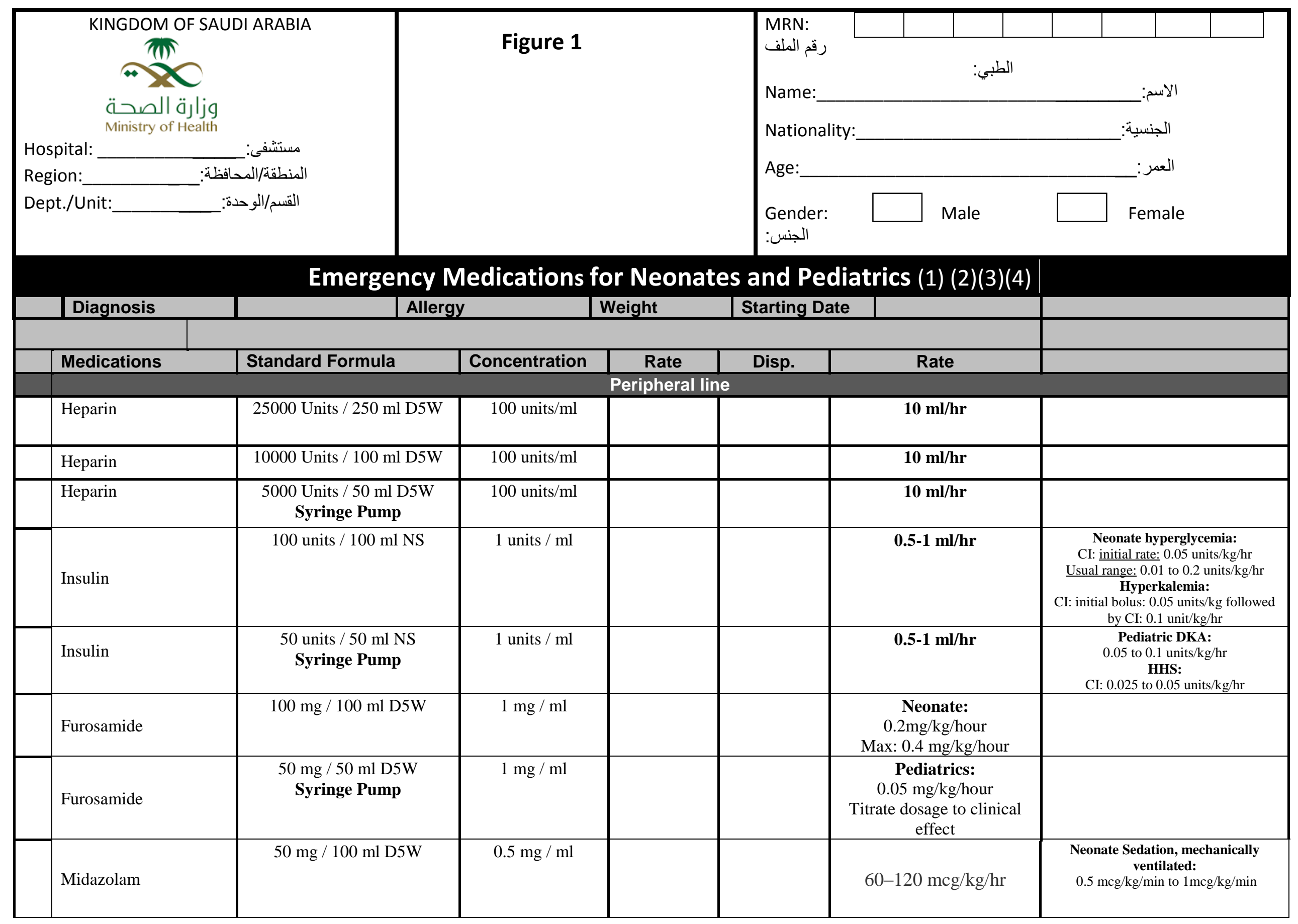




\begin{tabular}{|c|c|c|c|c|}
\hline Midazolam & $\begin{array}{l}5 \mathrm{mg} / 10 \mathrm{ml} \text { D5W } \\
\text { Syringe Pump }\end{array}$ & $1 \mathrm{mg} / \mathrm{ml}$ & $60-120 \mathrm{mcg} / \mathrm{kg} / \mathrm{hr}$ & $\begin{array}{c}\text { Pediatric, Sedation, mechanically } \\
\text { ventilated: } \\
1 \text { to } 2 \mathrm{mgg} / \mathrm{kg} / \mathrm{min} \\
\text { Range: } 0.4 \text { to } 6 \mathrm{mcg} / \mathrm{kg} / \mathrm{min} \\
\text { Status epilepticus: } \\
\text { CI: } 0.83 \text { to } 33.3 \mathrm{mc} / \mathrm{kg} / \mathrm{min} \\
\end{array}$ \\
\hline Fentanyl & $\begin{array}{l}100 \mathrm{mcg} / 10 \mathrm{ml} \\
\text { Syringe Pump }\end{array}$ & $10 \mathrm{mcg} / \mathrm{ml}$ & $\begin{array}{c}\text { Neonate: } \\
0.5-5 \mathrm{mcg} / \mathrm{kg} / \text { hour } \\
\\
\text { Pediatrics: } \\
\text { 1- } 5 \mathrm{mcg} / \mathrm{kg} / \text { hour }\end{array}$ & \\
\hline Sodium Nitroprusside & $\begin{array}{c}50 \mathrm{mg} / 250 \mathrm{ml} \\
\text { PROTECT FROM LIGHT } \\
\end{array}$ & $200 \mathrm{mcg} / \mathrm{ml}$ & $(0.5--10) \mathrm{mcg} / \mathrm{kg} / \mathrm{min}$ & \\
\hline Sodium Nitroprusside & $\begin{array}{l}10 \mathrm{mg} / 50 \mathrm{ml} \mathrm{D} 5 \mathrm{~W} \\
\text { Syringe Pump }\end{array}$ & $200 \mathrm{mcg} / \mathrm{ml}$ & $(0.5--10) \mathrm{mcg} / \mathrm{kg} / \mathrm{min}$ & \\
\hline Nitroglycerin & $50 \mathrm{mg} / 250 \mathrm{ml}$ D5W & $200 \mathrm{mcg} / \mathrm{ml}$ & $1-5 \mathrm{mcg} / \mathrm{min}$ & \multirow{2}{*}{$\begin{array}{c}\text { Neonate } \\
=1-3 \mathrm{mcg} / \mathrm{kg} / \mathrm{min} \\
\mathrm{Max}=5 \mathrm{mcg} / \mathrm{kg} / \mathrm{min} \\
\text { Children } \\
=1-5 \mathrm{mcg} / \mathrm{kg} / \mathrm{min} \\
\mathrm{Max}=10 \mathrm{mcg} / \mathrm{kg} / \mathrm{min}\end{array}$} \\
\hline Nitroglycerin & $\begin{array}{l}10 \mathrm{mg} / 50 \mathrm{ml} \mathrm{D} 5 \mathrm{~W} \\
\text { Syringe Pump }\end{array}$ & $200 \mathrm{mcg} / \mathrm{ml}$ & $1-5 \mathrm{mcg} / \mathrm{min}$ & \\
\hline Vasopressin & $\begin{array}{l}80 \text { units / } 100 \mathrm{ml} \mathrm{NS} \\
\text { GIT Preparation }\end{array}$ & 0.8 units / ml & $0.1-1.5$ units / min & \\
\hline Vasopressin & $\begin{array}{l}40 \text { units / } 50 \mathrm{ml} \mathrm{NS} \\
\text { GIT Preparation } \\
\text { Syringe Pump } \\
\end{array}$ & 0.8 units / $\mathrm{ml}$ & $0.1-1.5$ units / min & \\
\hline Vasopressin & $\begin{array}{l}20 \text { units / } 100 \mathrm{ml} \mathrm{NS} \\
\text { Cardiac Preparation }\end{array}$ & 0.2 units / ml & $0.01-0.06$ units / $\mathrm{min}$ & $\begin{array}{l}\text { Neonate shock: } \\
0.01 \quad \text { to } 0.6 \text { units/kg/hour } \\
\text { Infants, children and adolescents } \\
\text { shock: } \\
0.01 \text { to } 0.48 \text { units } / \mathrm{kg} / \mathrm{hour} \\
\\
\text { GI hemorrhage children adolescents: } \\
\text { CI: } 2 \text { to } 5 \text { miliunits//kg/min } \\
\text { Max: } 10 \text { miliunits } / \mathrm{kg} / \mathrm{min}\end{array}$ \\
\hline Vasopressin & $\begin{array}{l}10 \text { units / } 50 \mathrm{ml} \mathrm{NS} \\
\text { Cardiac Preparation } \\
\text { Syringe Pump }\end{array}$ & 0.2 units / $\mathrm{ml}$ & $0.01-0.06$ units / $\mathrm{min}$ & \\
\hline Aminophylline & $500 \mathrm{mg} / 500 \mathrm{ml}$ DW5 & $1 \mathrm{mg} / \mathrm{ml}$ & $(0.1--1.2) \mathrm{mg} / \mathrm{kg} / \mathrm{hr}$ & $\begin{array}{c}\text { Infants } 6 \text { to } 52 \text { wks: } \\
\text { Dose }(\mathrm{mg} / \mathrm{kg} / \mathrm{hour})=[(0.008 \mathrm{X} \text { age in } \\
\text { weeks })+0.21] \text { divided by } 0.79 \\
\end{array}$ \\
\hline Aminophylline & $500 \mathrm{mg} / 250 \mathrm{ml}$ DW5 & $2 \mathrm{mg} / \mathrm{ml}$ & $(0.1--1.2) \mathrm{mg} / \mathrm{kg} / \mathrm{hr}$ & \\
\hline Aminophylline & $500 \mathrm{mg} / 100 \mathrm{ml}$ DW5 & $5 \mathrm{mg} / \mathrm{ml}$ & $(0.1--1.2) \mathrm{mg} / \mathrm{kg} / \mathrm{hr}$ & \\
\hline Aminophylline & $\begin{array}{l}250 \mathrm{mg} / 50 \mathrm{ml} \mathrm{DW} 5 \\
\text { Syringe Pump }\end{array}$ & $5 \mathrm{mg} / \mathrm{ml}$ & $(0.1--1.2) \mathrm{mg} / \mathrm{kg} / \mathrm{hr}$ & \\
\hline
\end{tabular}




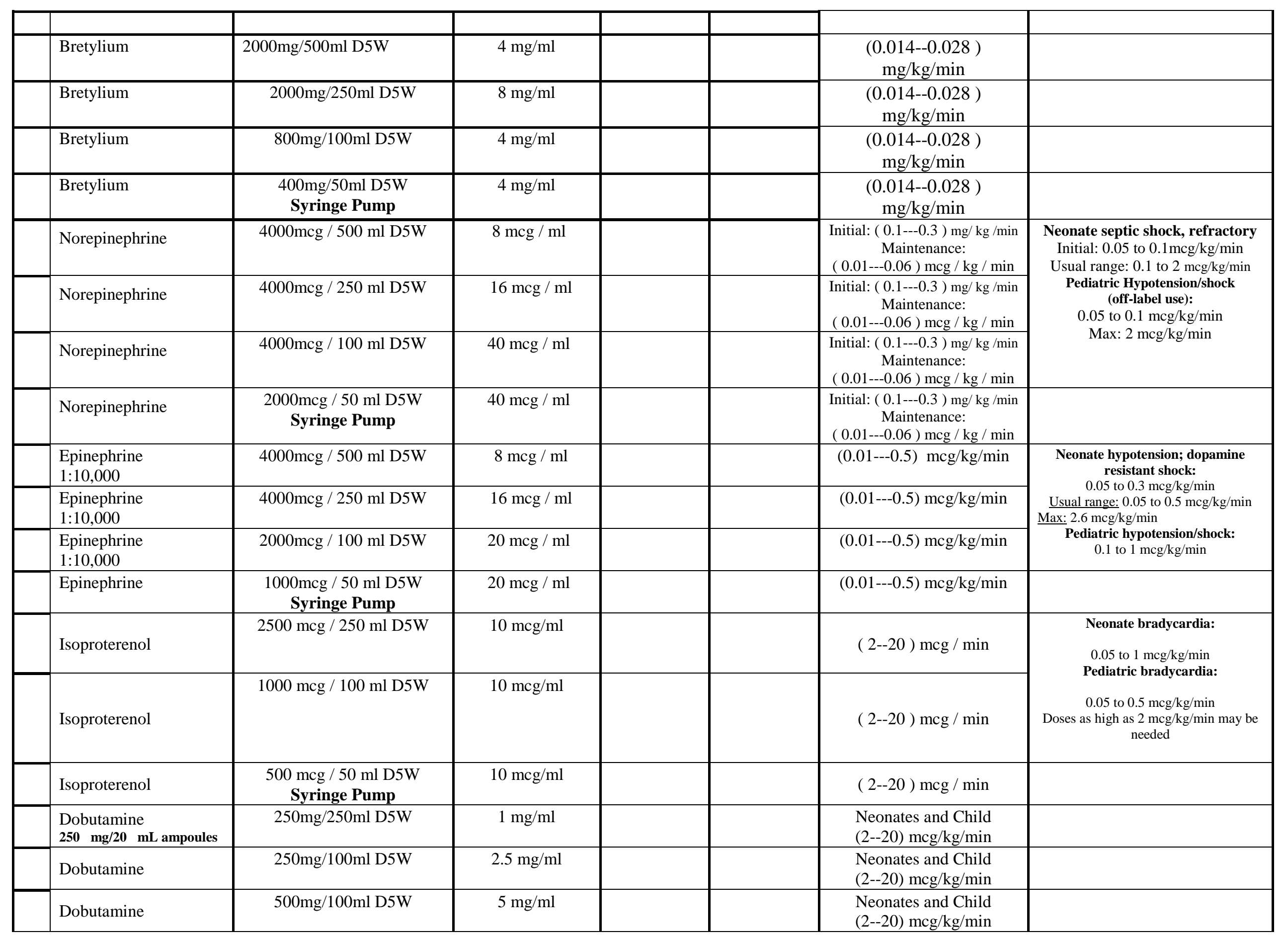




\begin{tabular}{|c|c|c|c|c|c|c|}
\hline & Dobutamine & $\begin{array}{l}250 \mathrm{mg} / 50 \mathrm{ml} \mathrm{D} 5 \mathrm{~W} \\
\text { Syringe Pump }\end{array}$ & $5 \mathrm{mg} / \mathrm{ml}$ & & $\begin{array}{l}\text { Neonates and Child } \\
(2--20) \mathrm{mcg} / \mathrm{kg} / \mathrm{min}\end{array}$ & \\
\hline & Dopamine & 400mg/250ml DW5 & $1.6 \mathrm{mg} / \mathrm{ml}$ & & $(1-20) \mathrm{mcg} / \mathrm{kg} / \mathrm{min}$ & \\
\hline & Dopamine & $160 \mathrm{mg} / 100 \mathrm{ml}$ DW5 & $1.6 \mathrm{mg} / \mathrm{ml}$ & & $(1-20) \mathrm{mcg} / \mathrm{kg} / \mathrm{min}$ & \\
\hline & Dopamine & $\begin{array}{l}80 \mathrm{mg} / 50 \mathrm{ml} \text { DW5 } \\
\text { Syringe Pump }\end{array}$ & $1.6 \mathrm{mg} / \mathrm{ml}$ & & $(1-20) \mathrm{mcg} / \mathrm{kg} / \mathrm{min}$ & \\
\hline & Dopamine & $800 \mathrm{mg} / 250 \mathrm{ml} \mathrm{DW} 5$ & $3.2 \mathrm{mg} / \mathrm{ml}$ & & $(1-20) \mathrm{mcg} / \mathrm{kg} / \mathrm{min}$ & \\
\hline & Dopamine & $320 \mathrm{mg} / 100 \mathrm{ml}$ DW5 & $3.2 \mathrm{mg} / \mathrm{ml}$ & & $(1-20) \mathrm{mcg} / \mathrm{kg} / \mathrm{min}$ & \\
\hline & Dopamine & $\begin{array}{c}\text { 160mg/50ml DW5 } \\
\text { Syringe Pump }\end{array}$ & $3.2 \mathrm{mg} / \mathrm{ml}$ & & $(1-20) \mathrm{mcg} / \mathrm{kg} / \mathrm{min}$ & \\
\hline & Lidocaine & $2000 \mathrm{mg} / 500 \mathrm{ml} \mathrm{D} 5 \mathrm{~W}$ & $4000 \mathrm{mcg} / \mathrm{ml}$ & & ( 1--4 ) $\mathrm{mg} / \mathrm{min}$ & \multirow{3}{*}{ 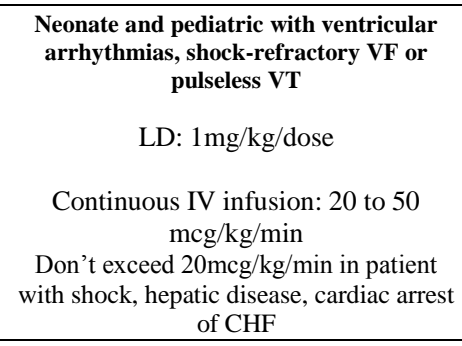 } \\
\hline & Lidocaine & $2000 \mathrm{mg} / 250 \mathrm{ml} \mathrm{D} 5 \mathrm{~W}$ & $8000 \mathrm{mcg} / \mathrm{ml}$ & & ( 1--4 ) $\mathrm{mg} / \mathrm{min}$ & \\
\hline & Lidocaine & $800 \mathrm{mg} / 100 \mathrm{ml} \mathrm{D} 5 \mathrm{~W}$ & $8000 \mathrm{mcg} / \mathrm{ml}$ & & $(1--4) \mathrm{mg} / \mathrm{min}$ & \\
\hline & Lidocaine & $\begin{array}{c}400 \mathrm{mg} / 50 \mathrm{ml} \mathrm{D} 5 \mathrm{~W} \\
\text { Syringe Pump }\end{array}$ & $8000 \mathrm{mcg} / \mathrm{ml}$ & & $(1--4) \mathrm{mg} / \mathrm{min}$ & \\
\hline & Procainamide & $1000 \mathrm{mg} / 250 \mathrm{ml} \mathrm{D} 5 \mathrm{~W}$ & $4000 \mathrm{mcg} / \mathrm{ml}$ & & $(1-6) \mathrm{mg} / \mathrm{min}$ & \multirow{3}{*}{$\begin{array}{l}\text { Neonate supraventricular tachycardia: } \\
\text { LD: } 7 \text { to } 10 \mathrm{mg} / \mathrm{kg} \text { over } 60 \mathrm{~min} \text { followed } \\
\text { By continuous infusion of } 20 \text { to } 80 \\
\mathrm{mcg} / \mathrm{kg} / \mathrm{min}\end{array}$} \\
\hline & Procainamide & $400 \mathrm{mg} / 100 \mathrm{ml}$ D5W & $4000 \mathrm{mcg} / \mathrm{ml}$ & & $(1-6) \mathrm{mg} / \mathrm{min}$ & \\
\hline & Procainamide & $\begin{array}{c}200 \mathrm{mg} / 50 \mathrm{ml} \mathrm{D} 5 \mathrm{~W} \\
\text { Syringe Pump }\end{array}$ & $4000 \mathrm{mcg} / \mathrm{ml}$ & & $(1-6) \mathrm{mg} / \mathrm{min}$ & \\
\hline \multicolumn{7}{|c|}{ 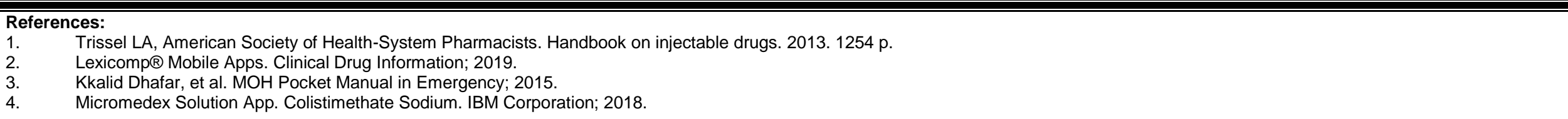 } \\
\hline \multicolumn{4}{|c|}{ Physician sig.: } & \multicolumn{2}{|l|}{ Pharmacist sig.: } & \\
\hline \multicolumn{3}{|c|}{ Nurse sig.: } & & Pharmacist sig.: & & \\
\hline
\end{tabular}

